\title{
Distinct Immunologic Properties of Soluble Versus Particulate Antigens
}

\author{
Clifford M. Snapper* \\ Department of Pathology, Uniformed Services University of the Health Sciences, Bethesda, MD, United States
}

Antigens in particulate form have distinct immunologic properties relative to soluble antigens. An understanding of the mechanisms and functional consequences of the distinct immunologic pathways engaged by these different forms of antigen is particularly relevant to the design of vaccines. It is also relevant regarding the use of therapeutic human proteins in clinical medicine that have been shown to aggregate, and perhaps as a result, elicit autoantibodies.

Keywords: bacteria, antibody, particle, vaccine, polysaccharide, autoantibody, marginal zone, antigen presentation

\section{DIFFERENCES BETWEEN SOLUBLE AND PARTICULATE ANTIGENS RELEVANT TO THE IMMUNE RESPONSE}

\section{OPEN ACCESS}

Edited by:

Joshua Milner,

National Institute of Allergy and Infectious Diseases (NIH),

United States

Reviewed by:

Philip Anton Van Der Merwe, University of Oxford, United Kingdom

Christoph Wülfing, University of Bristol, United Kingdom

${ }^{*}$ Correspondence: Clifford M. Snapper clifford.snapper@usuhs.edu

Specialty section: This article was submitted to T Cell Biology, a section of the journal

Frontiers in Immunology

Received: 28 November 2017 Accepted: 09 March 2018

Published: 21 March 2018

Citation:

Snapper CM (2018) Distinct Immunologic Properties of Soluble Versus Particulate Antigens.

Front. Immunol. 9:598. doi: 10.3389/fimmu.2018.00598
Relative to soluble antigens, antigens in particulate form are selectively internalized through antigenpresenting cell (APC) phagocytosis, with greater efficiency $(1,2)$ but with longer processing time (3), exhibit quantitative and qualitative differences in the antigenic epitopes generated (4), concentrate for extended periods within the marginal zone of the spleen (5), and are presented poorly, if at all, by splenic B cells (4), although efficiently internalized by peritoneal B1b cells (6). Signaling responses of APC can differ markedly in response to microbe-associated molecular patterns that are expressed in particulate versus soluble form (7). Various particulates, including intact bacteria activate the inflammasome resulting in production of $\operatorname{IL}-1 \beta(8,9)$, a cytokine that can augment $\mathrm{T}$ cell-dependent antibody responses (10). Phagocytosis of particulate antigens by APC also augment the calcineurin/ NFAT signaling pathway resulting in a higher level of immune stimulation (7).

\section{ANTIGEN PARTICULATION IMPROVES VACCINE IMMUNOGENICITY}

The aggregation or particulation of an antigen could increase its overall immunogenicity by enhancing B cell receptor cross-linking, leading to higher levels of B cell activation and targeting of internalized antigen to lysosomes with subsequent enhanced antigen presentation to $\mathrm{T}$ cells. Thus, DNA vaccination with plasmids encoding for weakly immunogenic GFP protein fused to either a long polyQ domain that triggers aggregation or a short polyQ domain that does not resulted in a significantly higher anti-GFP antibody response to the GFP aggregate, relative to its non-aggregated form, as well as to enhanced CTL activity (11). The attachment of several vaccines to bacterium-like particles derived from the Gram-positive bacterium Lactococcus lactis that was treated to become a predominantly peptidoglycan shell (1-2 $\mu \mathrm{m}$ in diameter), has demonstrated significant enhancement in $\mathrm{CD} 4^{+} \mathrm{T}$ cell responses, and promotion of antigen cross-presentation for $\mathrm{CD}^{+} \mathrm{T}$ cell activation (12). Nanoparticles can also be used as a platform for synchronizing delivery of antigens and adjuvants that can be targeted to specific cell types (13). The particle size to which antigen is associated may play a critical factor in the subsequent immune response. Thus, intradermal immunization of mice with ovalbumin (OVA) covalently attached to a range of 
carboxylated polystyrene microspheres $(0.02-2 \mu \mathrm{m}$ in diameter) in the absence of adjuvant demonstrated the highest OVA-specific $\mathrm{T}$ cell and antibody responses when using $0.04 \mu \mathrm{m}$, but not larger, beads (14). The immune response using $0.04-\mu \mathrm{m}$ beads was also higher relative to OVA immunizations using a number of different adjuvants. A subsequent study from this group further demonstrated a greater uptake by lung APC, and higher immune mediator release, following intratracheal instillation in mice of $0.05-\mu \mathrm{m}$, relative to $0.5-\mu \mathrm{m}$, diameter polystyrene nanoparticles (15). In this regard vaccines, in which recombinant proteins are displayed as virus-like particles, such as hepatitis B and human papilloma virus have proven clinically safe and highly effective in preventing the corresponding viral infections $(16,17)$. Many additional vaccination approaches using antigen particulation as a platform are currently under investigation (18-21), to mention only a few.

One underlying mechanism involved in the adjuvant effect of particulation is the targeted delivery of antigens to APCs in a concentrated form. We demonstrated that dendritic cells (DCs) were $>5,000$ times more efficient in the uptake and presentation of a bacterial protein to antigen-specific T-cells when delivered on the bacterial surface than when in soluble form, as a polysaccharide (PS)-protein conjugate (1). This likely reflected the fact that ingestion of a single bacterial particle by an APC effected the uptake of multiple copies of the associated protein. In contrast, the amount of soluble protein internalized via pinocytosis depended more heavily on the local concentration of antigen. Thus, the same total amount of soluble PS-protein conjugate delivered at a higher concentration was internalized $10-50$ times more efficiently by the DC (1). PS-protein conjugates include several licensed clinical vaccines, such as that for Haemophilus influenzae type b, Streptococcus pneumoniae, and Neisseria meningitidis, that are highly protective against infections with these PS-encapsulated extracellular bacteria (22).

\section{ANTIGEN PARTICULATION CAN BREAK IMMUNE TOLERANCE}

The immune system typically develops tolerance to self-proteins, yet autologous proteins used for therapeutic purposes often elicit antibody responses (23-25). Unwanted consequences of the latter include a reduction in drug efficacy (25) or development of significant pathologies $(24,26)$. Although the mechanism that underlies this break in immune tolerance is uncertain, possible contributors include degradation, modification, or aggregation of the protein $(27,28)$, or its contamination with Toll-like receptor (TLR) ligands $(29,30)$. In particular, aggregation has been implicated in immune responses to intravenous immunoglobulin, human growth hormone, and interferon $\alpha 2$ formulations $(27,28$, 31,32 ). Therapeutic proteins can aggregate in response to various stressors, such as agitation, freezing, and exposure to the air-liquid interface, during their manufacture, storage, and/or delivery to patients (33). Such aggregates may contain different secondary and tertiary structures that expose different epitopes, as well as create a repeating antigenic array for higher avidity $\mathrm{B}$ cell receptor binding and cross-linking. Indeed, immunization of rabbits or mice with virus-like particles to which arrays of self-antigens were conjugated induced strong antibody responses to those self-antigens $(34,35)$.

In light of the above, we directly tested the hypothesis that particulation of a soluble self-protein, i.e., mouse serum albumin (MSA), may lead to the breaking of self-tolerance in non-autoimmune mice, manifested by induction of $\mathrm{CD} 4^{+} \mathrm{T}$ celldependent antigen-specific antibody responses. This question was directly relevant to the fact that human serum albumin has a wide variety of clinical applications including intravascular volume expansion (36) and stabilization of protein therapeutics and vaccines (37). Certain properties of albumin would suggest a low likelihood of its eliciting autoantibodies. Thus, it exhibits limited polymorphism, including no known phenotypic variation in inbred mouse strains (38). In humans, although the gene for albumin is highly polymorphic, variations in the encoded protein sequences are rare (39). Moreover, during its synthesis, albumin is non-glycosylated, reducing its potential variability, although $6-15 \%$ may undergo nonenzymatic glycation in the blood $(40,41)$. Other properties of albumin, however, might suggest its potential for acting as an autoantigen. Thus, glycation alters the conformation and function of albumin (42). Albumin also binds various serum ligands (43) and interacts with a variety of host cells (44) and some bacterial pathogens (45-47). Bacteria can also bind albumin indirectly such as specific binding to heme that contains bound albumin (48).

In light of the potential for therapeutic proteins to aggregate as well as the observation that albumin can bind to intact bacterial surfaces, we wished to determine whether MSA covalently attached to bacteria-sized $(1 \mu \mathrm{m})$ latex beads could induce an autoimmune response in non-autoimmune $\mathrm{BALB} / \mathrm{c}$ mice. We observed that bead-associated, but not soluble MSA was indeed able to induce a $\mathrm{CD} 4^{+} \mathrm{T}$ cell-dependent MSA-specific IgG response (49). When MSA and PS (a T cell-independent antigen), were both covalently attached to the same latex beads, but not to each other we observed a $\mathrm{CD} 4^{+} \mathrm{T}$ cell-dependent augmented primary, and boosted secondary IgM and IgG anti-PS response. No such effects were observed for beads linked to PS alone or with MSA beads mixed with soluble PS. These responses were enhanced by, but did not require TLR stimulation. These results provided a potential mechanism, i.e., protein aggregation/particulation for the induction of responses to self-proteins normally unable to induce specific $\mathrm{T}$ cell or antibody responses. Thus, measures to minimize aggregation of proteins used for therapeutic purposes may lead to a reduction in elicitation of neutralizing or pathogenic antibodies. These data further confirmed our earlier demonstration using $1-\mu \mathrm{m}$ beads with associated PS and a foreign protein (50) that non-covalent association of protein and PS was sufficient to elicit T cell-dependent anti-PS responses. The simple association of PS and a foreign protein to a biocompatible particulate substrate might serve as a more cost-effective alternative to the use of PS-protein conjugate vaccines in which the antigens require covalent linkage, especially in developing countries where financial cost may be a limiting factor for widespread usage (51). 


\section{PS EXPRESSED AS A SOLUBLE PS-PROTEIN CONJUGATE VERSUS THE SAME PS EXPRESSED BY AN INTACT BACTERIUM ELICITS PS-SPECIFIC ANTIBODY RESPONSES FROM DISTINCT B CELL SUBSETS AND WITH DISTINCT IDIOTYPES}

Parenteral injection of particulate, in contrast to soluble, antigens results in their initial and prolonged concentration within the splenic marginal zone where they come into extended contact with marginal zone B (MZB) cells $(52,53)$. MZB cells, along with B-1 B cells play a major role in eliciting anti-PS responses (54). Thus, we wished to determine whether MZB cells mediated anti-PS responses to PS-expressing intact bacteria and whether or not this was also true for soluble PS-protein conjugates [the IgG anti-PS responses in both cases were shown to be $\mathrm{CD} 4^{+} \mathrm{T}$ cell-dependent $\left.(55,56)\right]$. For this purpose we utilized $\mathrm{Lsc}^{-/-}$mice. The function of the Lsc protein is to attenuate $\mathrm{G} \alpha 12 / 13$-mediated $\mathrm{G}$ protein-coupled receptor signaling with subsequent activation of RhoA signaling (57). Mice genetically deficient in Lsc $\left(\mathrm{Lsc}^{--}\right)$exhibit a marked defect in MZB migration from the marginal zone following immunization, precluding MZB interaction with $\mathrm{CD}^{+} \mathrm{T}$ cells (58). Lsc acts selectively on MZB cells $(58,59)$.

$\mathrm{Lsc}^{-1-}$ mice were immunized and boosted i.p. with intact, inactivated S. pneumoniae expressing the type 14 capsular PS or with a soluble conjugate of type $14 \mathrm{PS}$ and the S. pneumoniae-derived cell wall protein, pneumococcal surface protein $\mathrm{A}$. $\mathrm{Lsc}^{-1-}$ mice exhibited a nearly complete abrogation in the primary and secondary IgG anti-PS responses to intact S. pneumoniae, whereas no effects were observed on the same IgG anti-PS response to the soluble PS-protein conjugate $(1,60)$. In contrast, neither the T cell-independent IgM anti-PS responses to $S$. pneumoniae nor the T cell-dependent IgG anti-protein responses to $S$. pneumoniae or soluble PS-protein conjugate were affected in $\mathrm{Lsc}^{-/-}$relative to control mice. Thus, these data strongly suggested that particulation of associated PS and protein selectively recruited MZB cells to induce a T cell-dependent IgG anti-PS response. This was further supported by our observation that the IgG anti-PS response to a soluble PS-protein conjugate became completely dependent on MZB cells when the conjugate was adsorbed to the surface of an intact $S$. pneumoniae that lacked natural expression of both the relevant $\mathrm{PS}$ and protein (1).

The selective utilization of MZB cells for the IgG anti-type 14 PS response to intact $S$. pneumoniae was reflected in the observation that the majority of the elicited PS-specific IgG expressed a dominant idiotype, designated 44.1-Id that was not observed when using a soluble conjugate of type 14 PS and protein (61). The idiotype of an antibody is defined as the epitope(s) within the variable region that uniquely defines the specificity of the antibody for its cognate antigen. Of note, attachment of the soluble conjugate to $1-\mu \mathrm{m}$ latex beads or to the surface of an intact $S$. pneumoniae lacking the relevant PS and protein referred to earlier, resulted in a switch to significant 44.1-Id expression in the elicited IgG anti-PS response. Usage of the 44.1-Id was linked to the $I g h^{\mathrm{a}}$, but not $I g h^{\mathrm{b}}$, allotype. These results indicated that different antigenic forms of the same capsular PS can recruit distinct B cell clones expressing characteristic idiotypes under genetic control, and strongly suggested that the 44.1-Id is derived from MZB cells.

\section{ANTIBODY RESPONSES TO SOLUBLE ANTIGENS INVOLVE DISTINCT APCS RELATIVE TO ANTIGENS EXPRESSED BY INTACT BACTERIA}

Little is known regarding the specific APCs that initiate T cell activation during $\mathrm{T}$ cell-dependent (TD) antibody responses to soluble antigens versus complex particulate antigens, such as inactivated, intact extracellular bacteria. Of note, aluminum salts ("alum") are often used as adjuvants when immunizing with soluble antigens in various experimental systems, and are themselves particulate. However, antigen adsorbed to alum does not behave as a particulate antigen (1). Thus, DC exposed to alum-adsorbed antigen exhibited facilitated antigen uptake, but did not internalize the alum particles themselves (62).

Dendritic cells, monocytes (and monocyte-derived cells), and macrophages, all of which can serve as APCs, are members of the mononuclear phagocyte system that can be distinguished phenotypically $(63,64)$. Collectively, they play dominant roles as APCs for $\mathrm{CD}^{+} \mathrm{T}$ cells (63). Mouse DC within the spleen are further divided into conventional (classical) (c)DC [either $\mathrm{CD} 8 \alpha^{+}$or $\left.\mathrm{CD} 11 \mathrm{~b}^{+}\right]$and plasmacytoid DC $(63,65-67)$. Although DC are efficient in uptake of soluble antigens, they also exhibit phagocytic activity. Mouse monocytes are classified as Ly6 $\mathrm{C}^{\text {hi }}$ ("classical monocytes") and Ly6C lo ("non-classical monocytes") $(63,68)$. Ly6 $\mathrm{C}^{\text {hi }}$ monocytes, in particular can internalize and transport antigen to secondary lymphoid organs such as the spleen, where they mature into APCs capable of activating naïve T cells. They are then referred to, generally as monocyte-derived cells $(63,69,70)$. Monocyte-derived cells appear to be especially efficient in capturing intact bacteria (71). Macrophages are highly efficient at phagocytosis and play a major role in clearing senescent and apoptotic cells, cellular debris, and pathogens, but are also capable of acting as APC to activate T cells (72). In mouse spleen, macrophages are further divided into red pulp macrophages (73), marginal zone macrophages, and marginal metallophilic macrophages, the latter two located within the MZ (52).

In light of the observation that uptake of intact bacteria and soluble antigens by APCs are skewed toward phagocytosis versus endocytosis or pinocytosis, respectively, we predicted that injection into mice of clodronate-containing liposomes (CL) $(74,75)$, which are internalized and toxic to highly phagocytic cells, would inhibit $\mathrm{CD}^{+} \mathrm{T}$ cell-dependent IgG responses to antigens expressed by intact bacteria but not isolated soluble antigens. Splenic macrophages and monocytes (and monocytederived cells), but not conventional DCs or neutrophils, were depleted by i.v. injection of CL (76). Surprisingly, injection of CL markedly inhibited protein-specific IgG responses to a soluble PS-OVA conjugate or OVA alone, as well as to intact, inactivated 
S. pneumoniae. In both instances, CL-mediated inhibition of protein-specific IgG responses was associated with a significant reduction in the formation of germinal centers and the differentiation of $\mathrm{CD}^{+} \mathrm{T}$ cells into germinal center $\mathrm{T}$ follicular helper cells. However, CL injection which largely abrogated the proliferative response of adoptively transferred OVA peptidespecific transgenic $\mathrm{CD} 4^{+} \mathrm{T}$ cells in response to immunization with $S$. pneumoniae expressing OVA peptide, did not inhibit $\mathrm{T}$ cell proliferation in response to soluble PS-OVA or OVA alone. In this regard, monocyte-derived cells depleted by CL, internalized S. pneumoniae in vivo, whereas in contrast CD $11 \mathrm{c}^{\text {low }}$ DCs, unaffected by CL injection, internalized soluble OVA. Ex vivo isolation and coculture of these respective APCs from $S$. pneumoniae- or OVA-immunized mice with OVA-specific $\mathrm{T}$ cells, in the absence of exogenous antigen, demonstrated their selective ability to induce $\mathrm{T}$ cell activation. These data provided strong support to the notion that distinct APCs initiate CD4 ${ }^{+}$ $\mathrm{T}$ cell activation in response to antigen expressed by intact bacteria versus antigen in soluble form. However, CL-sensitive cells appear necessary for the subsequent IgG responses to both forms of antigen (76).

These studies using CL are consistent with earlier studies demonstrating a significant CL-mediated reduction in TNPspecific IgG antibody-forming cells following i.v. immunization with other micron-sized, particulate antigens including TNPsheep red blood cells (77) or TNP-Lactobacillus acidophilus (78), or reduction in serum titers of IgG anti-human serum albumin in response to liposome-associated human serum albumin (79). However, these studies provided no mechanistic basis for these observations. Similarly, i.p. injection of CL resulted in a marked inhibition in priming of $\mathrm{CD} 4^{+} \mathrm{T}$ cells, including IFN $-\gamma^{+}$T cells, following i.p. infection with live Salmonella typhimurium that was associated with a reduced accumulation of monocyte-derived cells in the spleen (80). However, in contrast to our findings, CL had no effect on the S. typhimurium-induced IgG2a plasma blast response and both monocyte-derived cells and conventional DC from $S$. typhimurium-infected mice could activate $S$. typhimurium-specific $\mathrm{CD}^{+} \mathrm{T}$ cells ex vivo, in the absence of exogenous antigen (80). The use of a live Gram-negative bacterium in this former study, as opposed to a Gram-positive, heat-killed bacterium used in this study, may potentially underlie the observed differences. Of note, i.v. injection of CL failed to inhibit humoral immune responses to smaller, nanometer-sized particles (i.e., inactivated rabies virus or immune-stimulating complexes containing rabies virus antigens) immunized via the i.v. route (81). Collectively, these data add further support to the notion that antigens in particulate form have distinct immunologic properties relative to soluble antigens.

\section{REFERENCES}

1. Colino J, Chattopadhyay G, Sen G, Chen Q, Lees A, Canaday DH, et al. Parameters underlying distinct $\mathrm{T}$ cell-dependent polysaccharide-specific IgG responses to an intact gram-positive bacterium versus a soluble conjugate vaccine. J Immunol (2009) 183:1551-9. doi:10.4049/jimmunol. 0900238

\section{CONCLUSION AND FUTURE DIRECTIONS}

Antigens expressed in particulate/aggregated form exhibit distinct immunologic properties relative to corresponding antigens in soluble form. Cells with high phagocytic activity selectively internalize particulate antigens and do so with relatively high efficiency. Antigen within the particle is displayed in multiple copies facilitating high avidity multivalent B cell cross-linking resulting in higher and sustained levels of $\mathrm{B}$ cell activation and antigen internalization for presentation to $\mathrm{CD} 4^{+} \mathrm{T}$ cells. This promotes higher antibody responses to foreign proteins but also a higher likelihood of generating autoantibody-secreting cells. Antigen particulation also allows for coexpression of adjuvant and cell targeting moieties for more efficient and/or targeted immune responses. Particulation itself may further activate the inflammasome and provide intrinsic adjuvant activity. Finally, particles may localize to the splenic marginal zone that may facilitate engagement of MZB that express specialized functional properties. An understanding of the unique immunologic properties of antigens in particulate form should guide future design of vaccines and protein therapeutics.

The following unanswered questions merit further study: (1) how do conventional B cells extract and present antigens from intact bacteria or protozoans in light of their inability to phagocytose particles of $\geq 1 \mu \mathrm{m}$ size, (2) what is the significance of the differential usage of select APCs in response to soluble versus particulate antigens on the subsequent nature of the immune response, (3) what is the mechanism by which particulate or aggregated antigens break immunologic tolerance, (4) what are the precise features (e.g., size, composition, organization) of particulate antigens that lead to optimal immune responses, and (5) can directing antigen to MZB cells through particulation be exploited clinically to alter the quantity or quality of the immune response.

\section{AUTHOR CONTRIBUTIONS}

The author confirms being the sole contributor of this work and approved it for publication.

\section{ACKNOWLEDGMENTS}

The author thanks Drs. Jesus Colino, Swagata Kar, and Gouri Chattopadhyay for the research cited from the author's laboratory.

\section{FUNDING}

Supported by N.I.H. 2R01-AI49192 and U.S.U.H.S. Dean's Research and Education Endowment.

2. Kovacsovics-Bankowski M, Clark K, Benacerraf B, Rock KL. Efficient major histocompatibility complex class I presentation of exogenous antigen upon phagocytosis by macrophages. Proc Natl Acad Sci U S A (1993) 90:4942-6. doi:10.1073/pnas.90.11.4942

3. Ziegler HK, Orlin CA, Cluff CW. Differential requirements for the processing and presentation of soluble and particulate bacterial antigens by macrophages. Eur J Immunol (1987) 17:1287-96. doi:10.1002/eji.1830170911 
4. Vidard L, Kovacsovics-Bankowski M, Kraeft SK, Chen LB, Benacerraf B, Rock KL. Analysis of MHC class II presentation of particulate antigens of B lymphocytes. J Immunol (1996) 156:2809-18.

5. Kraal G, Ter Hart H, Meelhuizen C, Venneker G, Claassen E. Marginal zone macrophages and their role in the immune response against $\mathrm{T}$-independent type 2 antigens: modulation of the cells with specific antibody. Eur J Immunol (1989) 19:675-80. doi:10.1002/eji.1830190416

6. Gao J, Ma X, Gu W, Fu M, An J, Xing Y, et al. Novel functions of murine B1 cells: active phagocytic and microbicidal abilities. Eur J Immunol (2012) 42:982-92. doi:10.1002/eji.201141519

7. Fric J, Zelante T, Ricciardi-Castagnoli P. Phagocytosis of particulate antigens - all roads lead to calcineurin/NFAT signaling pathway. Front Immunol (2014) 4:513. doi:10.3389/fimmu.2013.00513

8. Latz E, Xiao TS, Stutz A. Activation and regulation of the inflammasomes. Nat Rev Immunol (2013) 13:397-411. doi:10.1038/nri3452

9. Ferrand J, Ferrero RL. Recognition of extracellular bacteria by NLRs and its role in the development of adaptive immunity. Front Immunol (2013) 4:344. doi:10.3389/fimmu.2013.00344

10. Ben-Sasson SZ, Hu-Li J, Quiel J, Cauchetaux S, Ratner M, Shapira I, et al. IL-1 acts directly on CD4 $\mathrm{T}$ cells to enhance their antigen-driven expansion and differentiation. Proc Natl Acad Sci U S A (2009) 106:7119-24. doi:10.1073/ pnas.0902745106

11. Ilyinskii PO, Thoidis G, Sherman MY, Shneider A. Adjuvant potential of aggregate-forming polyglutamine domains. Vaccine (2008) 26:3223-6. doi:10.1016/j.vaccine.2008.03.078

12. Van Braeckel-Budimir N, Haijema BJ, Leenhouts K. Bacterium-like particles for efficient immune stimulation of existing vaccines and new subunit vaccines in mucosal applications. Front Immunol (2013) 4:282. doi:10.3389/ fimmu.2013.00282

13. Sehgal K, Ragheb R, Fahmy TM, Dhodapkar MV, Dhodapkar KM. Nanoparticle-mediated combinatorial targeting of multiple human dendritic cell (DC) subsets leads to enhanced T cell activation via IL-15-dependent DC crosstalk. J Immunol (2014) 193:2297-305. doi:10.4049/jimmunol.1400489

14. Fifis T, Gamvrellis A, Crimeen-Irwin B, Pietersz GA, Li J, Mottram PL, et al. Size-dependent immunogenicity: therapeutic and protective properties of nano-vaccines against tumors. J Immunol (2004) 173:3148-54. doi:10.4049/ jimmunol.173.5.3148

15. Hardy CL, Lemasurier JS, Mohamud R, Yao J, Xiang SD, Rolland JM, et al. Differential uptake of nanoparticles and microparticles by pulmonary APC subsets induces discrete immunological imprints. JImmunol (2013) 191:5278-90. doi:10.4049/jimmunol.1203131

16. Kash N, Lee MA, Kollipara R, Downing C, Guidry J, Tyring SK. Safety and efficacy data on vaccines and immunization to human papillomavirus. J Clin Med (2015) 4:614-33. doi:10.3390/jcm4040614

17. Hepatitis B vaccines WHO position paper. Oct 29. Weekly Epidemilogical Record. (Vol. 40), p. 405-20.

18. Riitho V, Walters AA, Somavarapu S, Lamp B, Rumenapf T, Krey T, et al. Design and evaluation of the immunogenicity and efficacy of a biomimetic particulate formulation of viral antigens. Sci Rep (2017) 7:13743. doi:10.1038/ s41598-017-13915-x

19. Singh B, Maharjan S, Cho KH, Cui L, Park IK, Choi YJ, et al. Chitosan-based particulate systems for the delivery of mucosal vaccines against infectious diseases. Int J Biol Macromol (2017). doi:10.1016/j.ijbiomac.2017.10.101

20. Ni D, Qing S, Ding H, Yue H, Yu D, Wang S, et al. Biomimetically engineered demi-bacteria potentiate vaccination against cancer. Adv Sci (Weinh) (2017) 4:1700083. doi:10.1002/advs.201700083

21. Karch CP, Doll T, Paulillo SM, Nebie I, Lanar DE, Corradin G, et al. The use of a $P$. falciparum specific coiled-coil domain to construct a self-assembling protein nanoparticle vaccine to prevent malaria. J Nanobiotechnology (2017) 15:62. doi:10.1186/s12951-017-0295-0

22. Goldblatt D, Assari T, Snapper C. The immunobiology of polysaccharide and conjugate vaccines. In: Siber GR editor. Pneumococcal Vaccines. Washington, DC: ASM Press (2008). p. 67-82.

23. De Groot AS, Scott DW. Immunogenicity of protein therapeutics. Trends Immunol (2007) 28:482-90. doi:10.1016/j.it.2007.07.011

24. Casadevall N, Nataf J, Viron B, Kolta A, Kiladjian JJ, Martin-Dupont P, et al. Pure red-cell aplasia and antierythropoietin antibodies in patients treated with recombinant erythropoietin. $N$ Engl J Med (2002) 346:469-75. doi:10.1056/ NEJMoa011931
25. Scagnolari C, Casato M, Bellomi F, De Pisa F, Turriziani O, Coviello R, et al. Serum interferon (IFN)-neutralizing antibodies and bioactivities of IFNs in patients with severe type II essential mixed cryoglobulinemia. Clin Diagn Lab Immunol (2003) 10:70-7. doi:10.1128/CDLI.10.1.70-77.2003

26. Li J, Yang C, Xia Y, Bertino A, Glaspy J, Roberts M, et al. Thrombocytopenia caused by the development of antibodies to thrombopoietin. Blood (2001) 98:3241-8. doi:10.1182/blood.V98.12.3241

27. Moore WV, Leppert P. Role of aggregated human growth hormone (hGH) in development of antibodies to hGH. J Clin Endocrinol Metab (1980) 51:691-7. doi:10.1210/jcem-51-4-691

28. Rosenberg AS. Effects of protein aggregates: an immunologic perspective. AAPS J (2006) 8:E501-7. doi:10.1208/aapsj080359

29. Viglianti GA, Lau CM, Hanley TM, Miko BA, Shlomchik MJ, MarshakRothstein A. Activation of autoreactive B cells by CpG dsDNA. Immunity (2003) 19:837-47. doi:10.1016/S1074-7613(03)00323-6

30. Christensen SR, Kashgarian M, Alexopoulou L, Flavell RA, Akira S, Shlomchik MJ.Toll-like receptor 9 controls anti-DNA autoantibody production in murine lupus. J Exp Med (2005) 202:321-31. doi:10.1084/jem.20050338

31. Hermeling S, Aranha L, Damen JM, Slijper M, Schellekens H, Crommelin DJ, et al. Structural characterization and immunogenicity in wild-type and immune tolerant mice of degraded recombinant human interferon alpha2b. Pharm Res (2005) 22:1997-2006. doi:10.1007/s11095-005-8177-9

32. Hermeling S, Schellekens H, Maas C, Gebbink MF, Crommelin DJ, Jiskoot W. Antibody response to aggregated human interferon alpha2b in wild-type and transgenic immune tolerant mice depends on type and level of aggregation. J Pharm Sci (2006) 95:1084-96. doi:10.1002/jps.20599

33. Chi EY, Krishnan S, Randolph TW, Carpenter JF. Physical stability of proteins in aqueous solution: mechanism and driving forces in nonnative protein aggregation. Pharm Res (2003) 20:1325-36. doi:10.1023/A:1025771421906

34. Zamora E, Handisurya A, Shafti-Keramat S, Borchelt D, Rudow G, Conant K, et al. Papillomavirus-like particles are an effective platform for amyloid-beta immunization in rabbits and transgenic mice. J Immunol (2006) 177:2662-70. doi:10.4049/jimmunol.177.4.2662

35. BachmannMF,RohrerUH,KundigTM,BurkiK,HengartnerH,ZinkernagelRM. The influence of antigen organization on B cell responsiveness. Science (1993) 262:1448-51. doi:10.1126/science.8248784

36. Hastings GE, Wolf PG. The therapeutic use of albumin. Arch Fam Med (1992) 1:281-7. doi:10.1001/archfami.1.2.281

37. Marth E, Kleinhappl B. Albumin is a necessary stabilizer of TBE-vaccine to avoid fever in children after vaccination. Vaccine (2001) 20:532-7. doi:10.1016 S0264-410X(01)00329-2

38. Petras ML. An inherited albumin variant in the house mouse, Mus musculus. Biochem Genet (1972) 7:273-7. doi:10.1007/BF00484827

39. Takahashi N, Takahashi Y, Blumberg BS, Putnam FW. Amino acid substitutions in genetic variants of human serum albumin and in sequences inferred from molecular cloning. Proc Natl Acad Sci U S A (1987) 84:4413-7. doi:10.1073/ pnas.84.22.8001

40. Iberg N, Fluckiger R. Nonenzymatic glycosylation of albumin in vivo. Identification of multiple glycosylated sites. J Biol Chem (1986) 261:13542-5.

41. Day JF, Thorpe SR, Baynes JW. Nonenzymatically glucosylated albumin. In vitro preparation and isolation from normal human serum. J Biol Chem (1979) 254:595-7.

42. Rondeau P, Navarra G, Cacciabaudo F, Leone M, Bourdon E, Militello V. Thermal aggregation of glycated bovine serum albumin. Biochim Biophys Acta (2010) 1804:789-98. doi:10.1016/j.bbapap.2009.12.003

43. Lu J, Stewart AJ, Sadler PJ, Pinheiro TJ, Blindauer CA. Albumin as a zinc carrier: properties of its high-affinity zinc-binding site. Biochem Soc Trans (2008) 36:1317-21. doi:10.1042/BST0361317

44. Brunskill NJ. Albumin receptors-structure and function. In: Duttaroy AK, Spener F editors. Cellular Proteins and Their Fatty Acids in Health and Disease. Weinheim: Wiley-VCH Verlag GmbH \& Co. KGaA (2003). p. 79-94.

45. Raeder R, Otten RA, Boyle MD. Comparison of albumin receptors expressed on bovine and human group G streptococci. Infect Immun (1991) 59:609-16.

46. Wideback K, Kronvall G. Surface receptors for serum albumin in group C and $\mathrm{G}$ streptococci show three different types of albumin specificity. Infect Immun (1982) 38:1154-63.

47. Retnoningrum DS, Cleary PP. M12 protein from Streptococcus pyogenes is a receptor for immunoglobulin G3 and human albumin. Infect Immun (1994) 62:2387-94. 
48. Bracken CS, Baer MT, Abdur-Rashid A, Helms W, Stojiljkovic I. Use of heme-protein complexes by the Yersinia enterocolitica HemR receptor: histidine residues are essential for receptor function. J Bacteriol (1999) 181:6063-72.

49. Colino J, Duke L, Snapper CM. Autologous albumin enhances the humoral immune response to capsular polysaccharide covalently coattached to bacteria-sized latex beads. Eur J Immunol (2014) 44:1433-43. doi:10.1002/ eji.201344266

50. Colino J, Duke L, Snapper CM. Noncovalent association of protein and capsular polysaccharide on bacteria-sized latex beads as a model for polysaccharide-specific humoral immunity to intact gram-positive extracellular bacteria. J Immunol (2013) 191:3254-63. doi:10.4049/jimmunol.1300722

51. Peltola $\mathrm{H}$. Worldwide Haemophilus influenzae type $\mathrm{b}$ disease at the beginning of the 21st century: global analysis of the disease burden 25 years after the use of the polysaccharide vaccine and a decade after the advent of conjugates. Clin Microbiol Rev (2000) 13:302-17. doi:10.1128/CMR.13.2.302-317.2000

52. Kraal G, Mebius R. New insights into the cell biology of the marginal zone of the spleen. Int Rev Cytol (2006) 250:175-215. doi:10.1016/S0074-7696(06)50005-1

53. Mebius RE, Kraal G. Structure and function of the spleen. Nat Rev Immunol (2005) 5:606-16. doi:10.1038/nri1669

54. Cerutti A, Cols M, Puga I. Marginal zone B cells: virtues of innate-like antibody-producing lymphocytes. Nat Rev Immunol (2013) 13:118-32. doi:10.1038/nri3383

55. Snapper CM. Differential regulation of polysaccharide-specific antibody responses to isolated polysaccharides, conjugate vaccines, and intact gram-positive versus gram-negative extracellular bacteria. Vaccine (2016) 34:3542-8. doi:10.1016/j.vaccine.2015.12.077

56. Snapper CM. Mechanisms underlying in vivo polysaccharide-specific immunoglobulin responses to intact extracellular bacteria. Ann N Y Acad Sci (2012) 1253:92-101. doi:10.1111/j.1749-6632.2011.06329.x

57. Hart MJ, Jiang X, Kozasa T, Roscoe W, Singer WD, Gilman AG, et al. Direct stimulation of the guanine nucleotide exchange activity of p115 RhoGEF by Galpha13. Science (1998) 280:2112-4. doi:10.1126/science.280.5372.2112

58. Rubtsov A, Strauch P, Digiacomo A, Hu J, Pelanda R, Torres RM. Lsc regulates marginal-zone $\mathrm{B}$ cell migration and adhesion and is required for the IgM T-dependent antibody response. Immunity (2005) 23:527-38. doi:10.1016/j. immuni.2005.09.018

59. Girkontaite I, Missy K, Sakk V, Harenberg A, Tedford K, Potzel T, et al. Lsc is required for marginal zone $\mathrm{B}$ cells, regulation of lymphocyte motility and immune responses. Nat Immunol (2001) 2:855-62. doi:10.1038/ni0901-855

60. Chattopadhyay G, Khan AQ, Sen G, Colino J, Dubois W, Rubtsov A, et al. Transgenic expression of $\mathrm{Bcl}-\mathrm{xL}$ or $\mathrm{Bcl}-2$ by murine $\mathrm{B}$ cells enhances the in vivo antipolysaccharide, but not antiprotein, response to intact Streptococcus pneumoniae. J Immunol (2007) 179:7523-34. doi:10.4049/jimmunol.179.11.7523

61. Colino J, Duke L, Arjunaraja S, Chen Q, Liu L, Lucas AH, et al. Differential idiotype utilization for the in vivo type 14 capsular polysaccharide-specific Ig responses to intact Streptococcus pneumoniae versus a pneumococcal conjugate vaccine. J Immunol (2012) 189:575-86. doi:10.4049/jimmunol.1200599

62. Flach TL, Ng G, Hari A, Desrosiers MD, Zhang P, Ward SM, et al. Alum interaction with dendritic cell membrane lipids is essential for its adjuvanticity. Nat Med (2011) 17:479-87. doi:10.1038/nm.2306

63. Guilliams M, Ginhoux F, Jakubzick C, Naik SH, Onai N, Schraml BU, et al. Dendritic cells, monocytes and macrophages: a unified nomenclature based on ontogeny. Nat Rev Immunol (2014) 14:571-8. doi:10.1038/nri3712

64. Chow A, Brown BD, Merad M. Studying the mononuclear phagocyte system in the molecular age. Nat Rev Immunol (2011) 11:788-98. doi:10.1038/nri3087

65. Wu L, Liu YJ. Development of dendritic-cell lineages. Immunity (2007) 26:741-50. doi:10.1016/j.immuni.2007.06.006

66. Onai N, Obata-Onai A, Schmid MA, Ohteki T, Jarrossay D, Manz MG. Identification of clonogenic common Flt3+M-CSFR+plasmacytoid and conventional dendritic cell progenitors in mouse bone marrow. Nat Immunol (2007) 8:1207-16. doi:10.1038/ni1518

67. Naik SH, Sathe P, Park HY, Metcalf D, Proietto AI, Dakic A, et al. Development of plasmacytoid and conventional dendritic cell subtypes from single precursor cells derived in vitro and in vivo. Nat Immunol (2007) 8:1217-26. doi:10.1038/ni1522
68. Geissmann F, Jung S, Littman DR. Blood monocytes consist of two principal subsets with distinct migratory properties. Immunity (2003) 19:71-82. doi:10.1016/S1074-7613(03)00174-2

69. Jenkins SJ, Hume DA. Homeostasis in the mononuclear phagocyte system. Trends Immunol (2014) 35:358-67. doi:10.1016/j.it.2014.06.006

70. Jakubzick C, Gautier EL, Gibbings SL, Sojka DK, Schlitzer A, Johnson TE, et al. Minimal differentiation of classical monocytes as they survey steady-state tissues and transport antigen to lymph nodes. Immunity (2013) 39:599-610. doi:10.1016/j.immuni.2013.08.007

71. Balazs M, Martin F, Zhou T, Kearney JF. Blood dendritic cells interact with splenic marginal zone B cells to initiate T-independent immune responses. Immunity (2002) 17:341-52. doi:10.1016/S1074-7613(02)00389-8

72. den Haan JM, Kraal G. Innate immune functions of macrophage subpopulations in the spleen. J Innate Immun (2012) 4:437-45. doi:10.1159/ 000335216

73. Austyn JM, Gordon S. F4/80, a monoclonal antibody directed specifically against the mouse macrophage. Eur J Immunol (1981) 11:805-15. doi:10.1002/ eji. 1830111013

74. van Rooijen N, van Nieuwmegen R. Elimination of phagocytic cells in the spleen after intravenous injection of liposome-encapsulated dichloromethylene diphosphonate. An enzyme-histochemical study. Cell Tissue Res (1984) 238:355-8. doi:10.1007/BF00217308

75. Van Rooijen N, Kors N, vd Ende M, Dijkstra CD. Depletion and repopulation of macrophages in spleen and liver of rat after intravenous treatment with liposome-encapsulated dichloromethylene diphosphonate. Cell Tissue Res (1990) 260:215-22. doi:10.1007/BF00318625

76. Kar S, Colino J, Snapper CM. Distinct cellular pathways for induction of CD4+ $\mathrm{T}$ cell-dependent antibody responses to antigen expressed by intact bacteria versus isolated soluble antigen. J Immunol (2016) 196:4204-13. doi:10.4049/ jimmunol.1502550

77. Delemarre FG, Kors N, van Rooijen N. Elimination of spleen and of lymph node macrophages and its difference in the effect on the immune response to particulate antigens. Immunobiology (1990) 182:70-8. doi:10.1016/ S0171-2985(11)80584-X

78. Buiting AM, De Rover Z, Kraal G, Van Rooijen N. Humoral immune responses against particulate bacterial antigens are dependent on marginal metallophilic macrophages in the spleen. Scand J Immunol (1996) 43:398-405. doi:10.104 6/j.1365-3083.1996.d01-54.x

79. Su D, Van Rooijen N. The role of macrophages in the immunoadjuvant action of liposomes: effects of elimination of splenic macrophages on the immune response against intravenously injected liposome-associated albumin antigen. Immunology (1989) 66:466-70.

80. Flores-Langarica A, Marshall JL, Bobat S, Mohr E, Hitchcock J, Ross EA, et al. T-zone localized monocyte-derived dendritic cells promote Th1 priming to Salmonella. Eur J Immunol (2011) 41:2654-65. doi:10.1002/eji.201141440

81. Claassen IJ, Osterhaus AD, Poelen M, Van Rooijen N, Claassen E. Antigen detection in vivo after immunization with different presentation forms of rabies virus antigen, II. Cellular, but not humoral, systemic immune responses against rabies virus immune-stimulating complexes are macrophage dependent. Immunology (1998) 94:455-60. doi:10.1046/j.1365-2567.1998.00539.x

Disclaimer: The opinions expressed herein are those of the author, and are not necessarily representative of those of the Uniformed Services University of the Health Sciences (USUHS), the Department of Defense (DOD), or the United States Army, Navy, or Air Force.

Conflict of Interest Statement: The author declares that the research was conducted in the absence of any commercial or financial relationships that could be construed as a potential conflict of interest.

Copyright (c) 2018 Snapper. This is an open-access article distributed under the terms of the Creative Commons Attribution License (CC BY). The use, distribution or reproduction in other forums is permitted, provided the original author(s) and the copyright owner are credited and that the original publication in this journal is cited, in accordance with accepted academic practice. No use, distribution or reproduction is permitted which does not comply with these terms. 